should have his or her friend, whose task it would be, in every way that human wit and kindness could devise, to make the little life easier and brighter, how great the good that might be done, how much of pain, and hardship, and sadness, might be removed.

I do not propose in this letter to go in great detail into the various modes in which the visitors we have in view would make themselves useful to the children they undertook to look after. The friendly visit, once a fortnight or so, would of itself be a bright spot in the sick child's existence. The more serious cases would be benefited by having as a visitor one able to convey medical suggestions, and to give the mother hints as to the nursing and management of the patient. In some instances little would be wanted, in others much. A proper bed, a perambulator, an occasicnal drive, suitable diet for a time, a sojourn in the country or by the seaa long list of ways of helping would not take long to frame.

Our aim is that there should not be in the poorer homes of London a single crippled or afflicted child without some kind friend attached to him, who would bring something of pleasure into his life, and who, being one of a large band of workers, and able to have recourse to an organisation possessing means and expezience, would often be in a position to give valuable advice and, where necessary, material help.

It will be seen that the visitors are not themselves expected to incur any great expense. Where they wish to do so, or to get the means of helping from private friends, their co-operation will be thankfully accepted, but they will be at liberty to apply to me for anything of a costly kind that may be required, and it is hoped that the public, as the plan becomes known, will enable the Society to meet all demands.

We believe that there are hundreds-nay, thousands - of men and women to whom this would be congenial work. It need not demand of them more than they can give. - A visitor need not of necessity have more than one case under his charge. He need not, unless he prefers it, belong to the Charity Organisation Society. All we ask is to be furnished with the names and addresses of those who will consent to "father" or "mother" one afflicted child, as near as may be to the locality where they live. We ask you to mention the scheme to all your friends, and kindly to send to me the names of any who, you think, might be willing to undertake the work.

May I, above all, enter your name in our book as one of our visitors for this special purpose? If, as I greatly hope, you will consent to this, please send me a line, addressed-Linut.-Col. Montefiore, 15, Buckingham Street, Strand, W.C.

A little time may elapse before you hear again, as there will be a good deal to arrange for before the work of visitation is actually commenced; but you may rely upon it that no neediess delay will be incurred.Believe me, yours faithfully,

E. Montefione, Lieut.-Col.

\section{THE STETHOSCOPE SONG.}

\author{
A Professional Ballad.
}

There was a young man in Boston town, He bought him a STETHOSCOPE nice and new, All mounted and finished and polished down, With an ivory cap and a stopper too.

It happened a spider within did crawl, And spun him a web of ample size,

Wherein there chanced one day to fall

A couple of very imprudent flies.

The first was a bottle-fly, big and blue,

The second was smaller, and thin and long:

So there was a concert between the two,

Like an octave flute and a tavern gong
Now being from Paris but recently,

This fine young man would show his skill ;

And so they gave him, his hand to try,

A hospital patient extremely ill.

Some said that his liver was short of bile,

And some that his heart was over size,

While some kept arguing all the while

He was crammed with tubercles up to his eyes.

This fine young man then up stepped he,

And all the doctors made a pause;

Said he,-The man must die, you see,

By the fifty-seventh of Louis's laws.

But since the case is a desperate one,

To explore his chest it may be well;

For if he should die, and it were not done,

You know the autopsy would not tell.

Then out his stethoscope he took,

And on it placed his curious ear;

Mon Dieu! said he, with a knowing look,

Why here is a sound that's mighty queer!

The bourdonnement is very clear, Amphoric buzzing, as I'm alive!

Five doctors took their turn to hear Amphoric buzzing, said all the five.

There's empyema beyond a doubt ;

We'll plunge a trocar in his side.-

The diagnosis was made out,

They tapped the patient; so he died.

Now such as hate new-fashioned toys Began to look extremely glum;

They said that rattles were made for boys, And vowed that his buzzing was all a hum.

There was an old lady had long been sick, And what was the matter none did know ; Her pulse was slow, though her tongue was quick; To her our knowing youth must go.

So there the nice old lady sat,

With phials and boxes all in a row ;

She asked the young doctor what he was at,

To thump her and tumble her ruffles so.

Now, when the stethoscope came out,

The flies began to buzz and whiz; -

Oh ho! the matter is clear, no doubt ;

An aneurism there plainly is.

The bruit de râpe and the bruit de scie

And the bruit de diable are all combined ;

How happy Bouillaud would be,

If he a case like this could find

Now, when the neighbouring doctors found A case so rare had been descried.

They every day her ribs did pound

In squads of twenty; so she died.

Then six young damsels, slight and frail,

Received this kind young doctor's cares ;

They all were getting slim and pale,

And short of breath on mounting stairs.

They all made rhymes with " sighs" and "skies," And loathed their puddings and buttered rolls, And dieted, much to their friends' surprise,

On pickles and pencils and chalk and coals

So fast their little hearts did bound,

The frightened insects buzzed the more;

So over all their chests he found

The râle sifflant, and the râle sonore.

He shook his head ; there's grave disease-

I greatly fear you all must die ;

A slight post mortem, if you please,

Surviving friends would gratify.

The six young damsels wept aloud, Which so prevailed on six young men,

That each his honest love avowed,

Whereat they all got well again.

This poor young man was all aghast ;

The price of stethoscopes came down ;

And so he was reduced at last

To practise in a country town.

The doctors being very sore,

A stethoscope they did devise,

That had a rammer to clear the bore

With a knob at the end to kill the flies.

Now use your ears. all you that can,

But don't forget to mind your eyes.

Or you may be cheated, like this young man

By a couple of silly, abnormal flies. OLIVER: WENDELL HOLMES. 